\title{
Changes in Biochemistry and Yield in Response to Biostimulants Applied in Bean (Phaseolus vulgaris L.)
}

\author{
Anna Kocira ${ }^{1, *(\mathbb{B}}$, Joanna Lamorska ${ }^{1}$, Rafał Kornas ${ }^{1}$, Natalia Nowosad ${ }^{1}$, \\ Marzena Tomaszewska ${ }^{1}$, Danuta Leszczyńska ${ }^{2}$, Katarzyna Kozłowicz ${ }^{3}$ and Sylwester Tabor ${ }^{4}$ (D) \\ 1 Institute of Agricultural Sciences, State School of Higher Education in Chełm, Pocztowa 54, 22-100 Chełm, \\ Poland; j.lamorska@gmail.com (J.L.); rkornas@pwsz.chelm.pl (R.K.); nnowosad@pwsz.chelm.pl (N.N.); \\ mtomaszewska@pwsz.chelm.pl (M.T.) \\ 2 Institute of Soil Science and Plant Cultivation, State Research Institute, Czartoryskich 8, 24-100 Puławy, \\ Poland; leszcz@iung.pulawy.pl \\ 3 Department of Biological Bases of Food and Feed Technologies, University of Life Sciences in Lublin, \\ Głęboka 28, 20-612 Lublin, Poland; katarzyna.kozlowicz@up.lublin.pl \\ 4 Department of Production Engineering, Logistics and Applied Computer Science, \\ Agricultural University Kraków, Balicka 116B, 30-149 Kraków, Poland; sylwester.tabor@urk.edu.pl \\ * Correspondence: akocira@pwsz.chelm.pl; Tel.: +48-82-565-8895
}

Received: 22 December 2019; Accepted: 28 January 2020; Published: 31 January 2020

\begin{abstract}
Biostimulants are preparations that favorably impact the growth, development, and yield of plants. The research objective was to examine the effect of the frequency of use of Kelpak, Terra Sorb Complex and Fylloton biostimulants on improving the yield and nutritional properties of beans. Been seeds (variety Oczko) were sown in the first week of May in 2015, 2016, and 2017. During the growing season, Fylloton (1\%), Terra Sorb Complex $(0.5 \%)$, and Kelpak $(1 \%)$ biostimulants were applied by single (BBCH 12-13) and double spraying of plants (BBCH 12-13, $\mathrm{BBCH} 61)$. All variants of treatment with biostimulants were compared with the control. Single application of Kelpak had a positive effect on increasing the number of pods. The double application of Kelpak increased the number and yield of seeds and protein contents. Double application of Fylloton increased the number of seeds, and application of Terra Sorb Complex increased the protein content in the beans. Application of all biostimulants increased the flavonoid content. Biostimulants containing seaweed (Kelpak-Ecklonia maxima extract) or amino-acid extracts (Fylloton-Ascophyllum nodosum extract and amino acids or Terra Sorb Complex-amino acids) increased the seed yield, while improving its quality by increasing the content of protein, polyphenols, and flavonoids. It was found that the double application of Kelpak biostimulant stimulated the yield and quality of beans to a greater extent.
\end{abstract}

Keywords: bean; biostimulants; amino acids; seaweed extract; yield; protein; phenols; flavonoids

\section{Introduction}

Agricultural production seeks technological solutions to improve the quality of yields. Therefore, biostimulants are increasingly popular as preparations that favorably impact the growth, development, and yield of plants [1,2], and they are safe for humans and environmentally friendly at the same time. Du Jardin [3] defines biostimulants as "any substance or microorganism applied to plants with the aim of enhancing nutrition efficiency, abiotic stress tolerance, and/or crop quality traits, regardless of its nutrient content". In addition, in order to develop legal provisions regarding the registration of biostimulants based on their specificity of operation, the European Biostimulants Industry Council (EBIC) was created. Currently, however, their registration is based on legal provisions on fertilizers and pesticides, and, for some of them, there is a marketing gap in many European Union (EU) member states [3-6]. 
Depending on the origin, there are natural or synthetic biostimulants. The former are obtained from biological material, and the latter are structurally similar and functionally identical to biological material [7]. The group of natural biostimulants includes preparations based on free amino acids, humic compounds, seaweed or fruit extracts, chitin and its derivative, chitosan, or microbial inoculants (free-living bacteria, fungi, and arbuscular mycorrhizal fungi) [8-10]. Of this group, biostimulants containing seaweed extract and protein hydrolysates are the most important category of substances that stimulate plant growth and development [11,12].

Biostimulants affect the metabolic processes occurring in the plant, stimulating the synthesis or activity of phytohormones, facilitating the growth of the root system, and improving the uptake, translocation, and utilization of nutrients, which determines the quality of the obtained yield [3,8-12]. Moreover, biostimulants increase plant resistance to abiotic stress factors such as drought, frost, salinity, and environmental contamination with heavy metals, which is probably caused by changes in the enzymatic activity of antioxidant compounds and their increased synthesis $[8,13]$.

In bean cultivation, the most commonly used are extracts of brown algae, e.g., of the species Ascophyllum nodosum, Laminaria spp., Ecklonia maxima, Sargassum spp., and Fucus spp. [14-17]. The positive effect of seaweed extracts on plant growth, development, and yield is attributed to the presence of phytohormones and low-molecular-weight compounds [18,19]. Some authors suggest that the polysaccharides and polyphenols present in the extract are also important, since they are allelochemicals which increase plant resistance to stress conditions [20-22]. Generally, organic and mineral compounds occur in seaweed extracts, the content of which depends on the algae species, their harvest date, and the applied extraction process [8]. The most important bioactive ingredients include proteins, enzymes, and amino acids (glycoproteins, metalloproteins, exogenous amino acids such as aspartic acid, glutamic acid, alanine), phytohormones (auxins, cytokinins, gibberellins, abscisic acid, polyamines, betaine, ethylene, brassinosteroids, brasinolide, castasterone), polyphenols (florotanins, ecol, floroglucin), phytalexins, vitamins $\left(C, B_{2}, B_{12}, D_{3}, E, K\right.$, niacin, panthotenic and folic acid), oligosaccharides, polysaccharides (agar, hyaluronic acid, alginic acid and its salts, carrageenans, fucans, mannitol, sorbitol, laminarin), macro- and microelements ( $\mathrm{Mg}, \mathrm{Cu}, \mathrm{Fe}, \mathrm{Br}, \mathrm{Zn}, \mathrm{I}, \mathrm{Mn}$ ), and essential unsaturated fatty acids (arachidonic, eicosapentenoic, $\gamma$-linolenic). Although vitamin A is not present in seaweed extracts, the presence of its precursors, i.e., carotene and possibly fucoxanthin was detected [14,23-31].

The positive effect of seaweed extracts on plants is visible in the stimulation of phytohormone synthesis, the uptake and translocation of nutrients, and soil conditioning, which is done by improving water-air conditions and the activity of beneficial soil microorganisms [32,33]. It was demonstrated that, even in low concentrations, seaweed extracts induce a number of physiological processes in the plant, contributing to their better growth, flowering, yield size, and quality, and improving the nutritional and storage quality of crop plants. In addition, the use of seaweed extracts increases the tolerance of plants to unfavorable growing conditions, for example, salinity, drought, or extreme temperatures $[12,34,35]$. The use of seaweed extract has a positive effect on plant growth and the size and quality of the obtained yield of tomato, eggplant, pepper, lettuce, beans, soybean, and wheat [13,25,36-46]. Undoubtedly, the beneficial effects of biostimulants on plants, under both optimal and stressful growing conditions, can be associated with stimulation of enzymatic activity related to carbon and nitrogen metabolism, the Krebs cycle, and glycolysis. Treatment of plants with these preparations may induce activity similar to that of phytohormones (auxin, gibberellin), which in effect improves their nutrition by modifying the structure of the root system $[8,9,47]$.

The biostimulant Kelpak (Kelp Products Ltd.) is based on an extract from Ecklonia maxima (Osbeck) Papenfuss and contains auxins $\left(11 \mathrm{mg} \cdot \mathrm{dm}^{-3}\right)$, cytokinins $\left(0.031 \mathrm{mg} \cdot \mathrm{dm}^{-3}\right)$, alginates $\left(1.5 \mathrm{~g} \cdot \mathrm{L}^{-1}\right)$, amino acids (total $\left.441.3 \mathrm{mg} \cdot 100 \mathrm{~g}^{-1}\right)$, mannitol $\left(2261 \mathrm{mg} \cdot \mathrm{L}^{-1}\right)$, neutral sugars $\left(1.08 \mathrm{~g} \cdot \mathrm{L}^{-1}\right)$, and small amounts of macroelements (N 0.09\%, P $90.7 \mathrm{mg} \cdot \mathrm{kg}^{-1}, \mathrm{~K} 7163.3 \mathrm{mg} \cdot \mathrm{kg}^{-1}, \mathrm{Ca} 190.4 \mathrm{mg} \cdot \mathrm{kg}^{-1}, \mathrm{Mg} 337.2 \mathrm{mg} \cdot \mathrm{kg}^{-1}$, $\mathrm{Na} 1623.7 \mathrm{mg} \cdot \mathrm{kg}^{-1}$ ) and microelements (mean composition: $\mathrm{Mn} 17.3 \mathrm{mg} \cdot \mathrm{kg}^{-1}, \mathrm{Fe} 40.7 \mathrm{mg} \cdot \mathrm{kg}^{-1}$, Cu $13.5 \mathrm{mg} \cdot \mathrm{kg}^{-1}$, Zn $17.0 \mathrm{mg} \cdot \mathrm{kg}^{-1}$, B $33.0 \mathrm{mg} \cdot \mathrm{kg}^{-1}$ ) [14,48]. The very high auxin-to-cytokinin ratio is 
responsible for stimulating the growth and development of the root system, which in turn contributes to better uptake and translocation of macro- and microelements, and it is associated with a significant increase in crops [48].

Biostimulants based on protein products and protein hydrolysates consist of a mixture of peptides, animal or vegetal amino acids, and single amino acids. Amino acids are a building material for proteins, but they are also precursors of phytohormones. They are involved in the synthesis of, e.g., vitamins, enzymes, terpenes, amines, purines, pyrimidines, and alkaloids [49,50]. They also play an important role in the process of pollination and fruit formation [51]. The application of exogenous amino acids, which are active in metabolic signaling (glutamate, histidine, proline, glycine, betaine), induces plant defense mechanisms by increasing their resistance to abiotic stress factors [8,52]. Due to the presence of specific peptides and precursors of phytohormone biosynthesis (tryptophan, which is the main precursor of IAA (Indole-3-acetic acid) biosynthesis and bioactive peptides), protein hydrolysates affect the hormonal balance of plants, which is related to stimulating plant growth [53]. The use of these biopreparations positively impacts the quality of agricultural produce, increasing the content of carotenoids, flavonoids, polyphenols, and ascorbic acid [54-57], and reducing the amount of undesirable compounds, e.g., nitrates [56].

Terra Sorb Complex (Bioiberica, S.A.U.) is a biostimulant containing $20 \%$ free vegetal amino acids and $5.5 \%$ total $\mathrm{N}$ (including $5 \%$ organic $\mathrm{N}$ ), $0.8 \% \mathrm{MgO}, 1.5 \% \mathrm{~B}, 1 \% \mathrm{Fe}, 0.1 \% \mathrm{Mn}, 0.001 \% \mathrm{Mo}, 0.1 \% \mathrm{Zn}$, and $25 \%$ organic matter.

The beneficial effect of biostimulants with seaweed extracts or amino acids on plant growth and development, and on the quantity and quality of the yield, regardless of its developmental stage, was confirmed in numerous studies [13,34,35,39-41,57-62]. An interesting solution is to combine these two components in a single preparation, as in the case of the Fylloton biostimulant (Biolchim Poland), which contains the extract of Ascophyllum nodosum (L.) Le Jolis, as well as vegetal amino acids. The composition of this preparation includes Ascophyllum nodosum extract, amino acid complexes of vegetal origin $37.5 \%$, organic nitrogen $6 \%$, organic carbon of biological origin $11 \%$, and organic substance $35 \%$.

Bean is an economically important legume that is sensitive to low temperatures in the early stages of its development and flowering. The use of biostimulants that positively affect the metabolic processes occurring in the plant, especially in the time of climate change, which causes stress factors for this sensitive plant, can be one of the elements contributing to the improvement in the quantity and quality of bean yield. Plant response to the biostimulant often depends on the variety, as demonstrated in earlier studies $[15,39,59,60]$. There are also no reports regarding the reaction of two-colored coat seed of bean to treatment with biostimulants. In view of the above and based on the importance being given to the improving crop yields, the research objective was to investigate the effect of the use of Kelpak, Terra Sorb Complex, and Fylloton biostimulants on improving the yield and nutritional properties of common bean (Phaseolus vulgaris L.) variety Oczko.

\section{Materials and Methods}

\subsection{Plant Materials and Growth Conditions}

The research material came from field studies carried out in the year 2015-2017 in Perespa (50 $66^{\prime}$ north (N); $23^{\circ} 63^{\prime}$ east (E)), Poland, on common beans (Phaseolus vulgaris L.), variety Oczko. The experiment was established in a random block system, in four replications, on an area of $10 \mathrm{~m}^{2}$. The experiment was established on an alkaline ( $\mathrm{pH}$ in $1 \mathrm{M} \mathrm{KCl-7.4)}$ soil of the brown rendzina subtype. Soil fertility level was as follows: phosphorus medium (12.6-14.2 mg $\mathrm{P}_{2} \mathrm{O}_{5}$ in $100 \mathrm{~g}$ of soil), potassium medium (15.3-17.1 $\mathrm{mg} \mathrm{K}_{2} \mathrm{O}$ in $100 \mathrm{~g}$ of soil), and magnesium medium (6.2-6.8 $\mathrm{mg} \mathrm{Mg}$ in $100 \mathrm{~g}$ of soil). In each year of research, the forecrop for common beans was winter wheat. Tillage for bean was carried out in accordance with good agricultural practice [63]. Pre-winter plowing was performed in the first week of November. In the spring, soil treatment combined with mineral fertilization was performed. Mineral fertilizers were in the following doses: $30 \mathrm{~kg} \mathrm{~N} \cdot \mathrm{ha}^{-1}, 60 \mathrm{~kg} \mathrm{P}_{2} \mathrm{O}_{5} \cdot \mathrm{ha}^{-1}$, and $120 \mathrm{~kg} \mathrm{~K}_{2} \mathrm{O} \cdot \mathrm{ha}^{-1}$. 
Mineral fertilization was used at a constant level throughout all experimental combinations. Beans of common bean, variety Oczko (with a red and white bean coat), were sown with a mechanical precision bean drill in the first week of May (2 May in 2015, 2016, and 2017) at a depth of 3-4 cm, in rows $45 \mathrm{~cm}$ apart, using 30 plants per $1 \mathrm{~m}^{2}$. Biostimulants Terra Sorb Complex, Kelpak, and Fylloton were used during the growing season, according to the experiment design (Table 1), and the obtained results were compared with the control, in which pure water was used for double spraying the plants. In individual years of research, biostimulants were used in time frames dependent on the development phase of plants, as shown in Table 1. Plants single sprayed with the biostimulant in BBCH 12-13, in the second period (plant stage of $\mathrm{BBCH} 61$ ), were sprayed with pure water.

Table 1. Overview of biostimulant application in bean variety Oczko cultivation.

\begin{tabular}{|c|c|c|c|c|c|c|}
\hline \multirow[b]{2}{*}{ Biostimulant } & \multirow[b]{2}{*}{ Concentration } & \multirow{2}{*}{$\begin{array}{l}\text { Number of Sprays and } \\
\text { Plant Developmental } \\
\text { Stages (BBCH) }\end{array}$} & \multirow{2}{*}{$\begin{array}{c}\text { Volume of Working } \\
\text { Solution/ } \\
\text { Working Pressure }\end{array}$} & \multicolumn{3}{|c|}{ Date } \\
\hline & & & & 2015 & 2016 & 2017 \\
\hline $\begin{array}{l}\text { Fylloton } \\
\text { (F) }\end{array}$ & $1 \%$ & $\begin{array}{c}\text { Single spraying: BBCH } \\
\text { 12-13 (SS) } \\
\text { Double spraying: BBCH } \\
\text { 12-13, BBCH } 61 \text { (DS) }\end{array}$ & $300 \mathrm{~L} \cdot \mathrm{ha}^{-1} / 0.30 \mathrm{MPa}$ & $\begin{array}{l}\text { June } 5 \\
\text { June 5, } \\
\text { June } 20\end{array}$ & $\begin{array}{l}\text { June } 7 \\
\text { June 7, } \\
\text { June } 23\end{array}$ & $\begin{array}{l}\text { June } 9 \\
\text { June 9, } \\
\text { June 26 }\end{array}$ \\
\hline $\begin{array}{l}\text { Terra Sorb } \\
\text { Complex } \\
\text { (TS) }\end{array}$ & $0.5 \%$ & $\begin{array}{c}\text { Single spraying: } \mathrm{BBCH} \\
12-13 \text { (SS) } \\
\text { Double spraying: BBCH } \\
\text { 12-13, BBCH } 61 \text { (DS) }\end{array}$ & $300 \mathrm{~L} \cdot \mathrm{ha}^{-1} / 0.30 \mathrm{MPa}$ & $\begin{array}{l}\text { June } 5 \\
\text { June 5, } \\
\text { June 20 }\end{array}$ & $\begin{array}{l}\text { June } 7 \\
\text { June 7, } \\
\text { June 23 }\end{array}$ & $\begin{array}{l}\text { June } 9 \\
\text { June 9, } \\
\text { June 26 }\end{array}$ \\
\hline $\begin{array}{c}\text { Kelpak } \\
(\mathrm{K})\end{array}$ & $1 \%$ & $\begin{array}{c}\text { Single spraying: BBCH } \\
\text { 12-13 (SS) } \\
\text { Double spraying: BBCH } \\
\text { 12-13, BBCH } 61 \text { (DS) }\end{array}$ & $300 \mathrm{~L} \cdot \mathrm{ha}^{-1} / 0.30 \mathrm{MPa}$ & $\begin{array}{l}\text { June } 5 \\
\text { June 5, } \\
\text { June 20 }\end{array}$ & $\begin{array}{l}\text { June } 7 \\
\text { June 7, } \\
\text { June } 23\end{array}$ & $\begin{array}{l}\text { June } 9 \\
\text { June 9, } \\
\text { June 26 }\end{array}$ \\
\hline
\end{tabular}

Abbreviations: single spraying BBCH 12-13-single spraying at the 2-3-leaf stage; double spraying BBCH 12-13, $\mathrm{BBCH} 61$-double spraying first at the 2-3-leaf stage and second at the beginning of bean blooming.

The plants were sprayed using a GARLAND FUM 12B backpack sprayer. The Lechler LU 120-03 atomizer was used, at a working pressure of $0.30 \mathrm{MPa}$, using $300 \mathrm{~L}$ of the working liquid per 1 ha. All variants of treatment with biostimulants were compared with the control, where plants were treated with the same volume of water (no biostimulant was applied). No pesticides were used in the cultivation, as pathogens, pests and weeds did not exceed the damage threshold. Plants were weeded manually. The average temperature and rainfall during the bean growing season are shown in Table 2. The weather station (W200P, Vector Instruments Ltd., Rhyl, UK) was located in the experimental field, in which the experiment was carried out, at $210 \mathrm{~m}$ above sea level.

After harvesting plants in the third week of August (22 August 2015; 27 August 2016; 24 August 2017), 20 plants were randomly selected from each plot, and the number of pods, number of seeds, seed yield, and weight of one thousand seeds was determined. The beans obtained from each plot were dried, ground in a laboratory mill, and sieved with a $0.310-\mathrm{mm}$ sieve. The flours were stored at $-20{ }^{\circ} \mathrm{C}$ and used for further chemical analysis. 
Table 2. Conditions during the growing seasons in bean variety Oczko cultivation in 2015-2017.

\begin{tabular}{|c|c|c|c|c|c|c|c|c|}
\hline \multirow[b]{3}{*}{ Month } & \multicolumn{6}{|c|}{ Year } & \multirow{2}{*}{\multicolumn{2}{|c|}{$\begin{array}{l}\text { Average from } \\
2002-2015\end{array}$}} \\
\hline & \multicolumn{2}{|c|}{2015} & \multicolumn{2}{|c|}{2016} & \multicolumn{2}{|c|}{2017} & & \\
\hline & $\begin{array}{c}\mathrm{T}\left({ }^{\circ} \mathrm{C}\right) \\
\text { Average } \\
(\mathrm{min} / \mathrm{max})\end{array}$ & $\begin{array}{c}\text { Rainfall } \\
\text { (mm) }\end{array}$ & $\begin{array}{c}\mathrm{T}\left({ }^{\circ} \mathrm{C}\right) \\
\text { Average } \\
(\mathrm{min} / \mathrm{max})\end{array}$ & $\begin{array}{c}\text { Rainfall } \\
(\mathrm{mm})\end{array}$ & $\begin{array}{c}\mathrm{T}\left({ }^{\circ} \mathrm{C}\right) \\
\text { Average } \\
(\mathrm{min} / \mathrm{max})\end{array}$ & $\begin{array}{c}\text { Rainfall } \\
\text { (mm) }\end{array}$ & $\mathrm{T}\left({ }^{\circ} \mathrm{C}\right)$ & $\begin{array}{c}\text { Rainfall } \\
\text { (mm) }\end{array}$ \\
\hline IV & $\begin{array}{c}8.2 \\
(-1.7 / 24.3)\end{array}$ & 30.1 & $\begin{array}{c}9.2 \\
(-1.2 / 22.6)\end{array}$ & 68.4 & $\begin{array}{c}7.7 \\
(-1.6 / 23.3)\end{array}$ & 37.2 & 8.6 & 41.9 \\
\hline $\mathrm{V}$ & $\begin{array}{c}12.7 \\
(1.5 / 24.9)\end{array}$ & 108.6 & $\begin{array}{c}13.8 \\
(2.6 / 26.7)\end{array}$ & 61.3 & $\begin{array}{c}13.7 \\
(-1.4 / 26.9)\end{array}$ & 100.0 & 12.6 & 64.1 \\
\hline VI & $\begin{array}{c}17.4 \\
(6.6 / 30.5)\end{array}$ & 14.1 & $\begin{array}{c}18.1 \\
(4.2 / 31.5)\end{array}$ & 97.1 & $\begin{array}{c}18.3 \\
(5.7 / 30.2)\end{array}$ & 38.6 & 17.8 & 68.3 \\
\hline VII & $\begin{array}{c}19.6 \\
(8.4 / 33.4)\end{array}$ & 59.2 & $\begin{array}{c}19.5 \\
(8.8 / 31.2)\end{array}$ & 107.6 & $\begin{array}{c}18.5 \\
(5.3 / 32.9)\end{array}$ & 61.1 & 18.8 & 79.4 \\
\hline VIII & $\begin{array}{c}21.6 \\
(5.6 / 35.5)\end{array}$ & 23.4 & $\begin{array}{c}18.2 \\
(7.1 / 30.7)\end{array}$ & 95.3 & $\begin{array}{c}19.5 \\
(4.3 / 34.4)\end{array}$ & 25.5 & 19.5 & 71.5 \\
\hline IX & $\begin{array}{c}15.1 \\
(4.2 / 34.5)\end{array}$ & 137.6 & $\begin{array}{c}15.2 \\
(1.6 / 28.7)\end{array}$ & 41.2 & $\begin{array}{c}13.2 \\
(-0.3 / 27.3)\end{array}$ & 100.4 & 14.0 & 69.6 \\
\hline Average/Total & 15.8 & 373.0 & 17.1 & 470.9 & 15.2 & 362.8 & 15.2 & 394.8 \\
\hline
\end{tabular}

\subsection{Determination of Polyphenols}

A ground sample of bean seeds of $0.25 \mathrm{~g}$ was weighed, to which $4 \mathrm{~cm}^{3}$ of extraction solution (acetone:water:hydrochloric acid 70:29:1) was added. The solutions were shaken for $1 \mathrm{~h}$. Then, $100 \mu \mathrm{L}$ of distilled water and $0.4 \mathrm{~mL}$ of Folina-Ciocalteu reagent were added to $100 \mu \mathrm{L}$ of extract, and, after $10 \mathrm{~min}, 2 \mathrm{~mL}$ of $10 \% \mathrm{Na}_{2} \mathrm{O}_{3}$ solution was added. After $30 \mathrm{~min}$, the absorbance of methanol was measured at $\lambda=725 \mathrm{~nm}$. The polyphenol content was calculated in $\mathrm{mg} \cdot 100 \mathrm{~g}^{-1}$, from the gallic acid calibration curve $\left(1 \mathrm{mg} \cdot \mathrm{mL}^{-1}\right)$.

\subsection{Determination of Flavonoids}

A ground sample of bean seeds of $0.25 \mathrm{~g}$ was weighed, to which $4 \mathrm{~cm}^{3}$ of extraction solution (acetic acid:methanol 1:19) was added. The solutions were shaken for $1 \mathrm{~h}$. Then, $0.1 \mathrm{~mL}$ of a $2 \% \mathrm{AlCl}_{3} \cdot 6 \mathrm{H}_{2} \mathrm{O}$ methanolic solution was added to $1 \mathrm{~mL}$ of the extract, together with $1.4 \mathrm{~mL}$ of $\mathrm{CH}_{3} \mathrm{COOH}$ methanolic solution (1:19). The sample was then incubated at $20{ }^{\circ} \mathrm{C}$ for $30 \mathrm{~min}$. Absorbance was measured at $\lambda=425 \mathrm{~nm}$ against methanol. The flavonoid content was calculated in $\mathrm{mg} \cdot 100 \mathrm{~g}^{-1}$, from the calibration curve for quercetin $\left(0.2 \mathrm{mg} \cdot \mathrm{mL}^{-1}\right)$.

\subsection{Determination of Proteins}

The protein content of bean extracts was determined using the Bradford reagent, according to the method of Redmile-Gordon et al. [57] with modifications. The Bradford reagent (150 $\mu \mathrm{L})$ was applied on a microplate and $50 \mu \mathrm{L}$ of assay or standard protein (BSA, bovine serum albumin) was added. The samples were shaken at room temperature for $15 \mathrm{~min}$. Absorbance at $595 \mathrm{~nm}$ was measured using an Epoch Microplate Spectrophotometer (BioTek-USA). The resulting protein was expressed in $\mathrm{mg}^{-\mathrm{g}^{-1}}$ of dry weight (DW).

\subsection{Statistical Analysis}

The statistical analysis was performed using the Statistica 10PL program by StatSoft ${ }^{\circledR}$. The normal distribution of variables was tested using the Shapiro-Wilk test. The one-way (for 2015, 2016, and 2017) and the two-way (for average 2015-2017) analysis of variance was used. The significance of the mean was determined using the Tukey test, at a significance level of $p<0.05$. 


\section{Results}

Based on the two-way ANOVA analysis, the effect of the number of applications and biostimulant treatment on seed yield, number of seeds, and phenol content in bean seeds was found (Table 3). The effect of biostimulant treatment on the number of pods, the weight of one thousand seeds, and the content of proteins and flavonoids in bean seeds were demonstrated. The interaction of biostimulant treatment with its number of applications regarding the impact on the number of seeds, as well as the content of protein and phenols in bean seeds, was found.

Table 3. Two-way ANOVA of number of applications and treatment of bean variety Oczko (average 2015-2017).

\begin{tabular}{|c|c|c|c|c|c|}
\hline Effect & $\begin{array}{l}\text { Sum of } \\
\text { Squares }\end{array}$ & $\begin{array}{l}\text { Degrees of } \\
\text { Freedom }\end{array}$ & $\begin{array}{c}\text { Mean } \\
\text { Squares }\end{array}$ & F Ratio & $p$-Values \\
\hline \multicolumn{6}{|c|}{ Seed yield } \\
\hline Intercept & $5,439,549$ & 1 & $5,439,549$ & $23,099.18$ & 0.000000 \\
\hline Number of applications & 3181 & 1 & 3181 & 13.51 & 0.000697 \\
\hline Treatment & 34,486 & 3 & 11,495 & 48.82 & 0.000000 \\
\hline Number of applications $\times$ treatment & 1510 & 3 & 503 & 2.14 & 0.110568 \\
\hline Error & 9419 & 40 & 235 & & \\
\hline \multicolumn{6}{|c|}{1000 seed weight } \\
\hline Intercept & $10,599,621$ & 1 & $10,599,621$ & $44,665.77$ & 0.000000 \\
\hline Number of applications & 314 & 1 & 314 & 1.32 & 0.257138 \\
\hline Treatment & 11,114 & 3 & 3705 & 15.61 & 0.000001 \\
\hline Number of applications $\times$ treatment & 281 & 3 & 94 & 0.40 & 0.757166 \\
\hline Error & 9492 & 40 & 237 & & \\
\hline \multicolumn{6}{|c|}{ Number of pods } \\
\hline Intercept & $2,570,576$ & 1 & $2,570,576$ & $10,667.40$ & 0.000000 \\
\hline Number of applications & 290 & 1 & 290 & 1.20 & 0.279127 \\
\hline Treatment & 15,025 & 3 & 5008 & 20.78 & 0.000000 \\
\hline Number of applications $\times$ treatment & 1506 & 3 & 502 & 2.08 & 0.117750 \\
\hline Error & 9639 & 40 & 241 & & \\
\hline \multicolumn{6}{|c|}{ Number of seeds } \\
\hline Intercept & $24,743,716$ & 1 & $24,743,716$ & $33,040.26$ & 0.000000 \\
\hline Number of applications & 22,838 & 1 & 22,838 & 30.50 & 0.000002 \\
\hline Treatment & 209,494 & 3 & 69,831 & 93.25 & 0.000000 \\
\hline Number of applications $\times$ treatment & 12,377 & 3 & 4126 & 5.51 & 0.002905 \\
\hline Error & 29,956 & 40 & 749 & & \\
\hline \multicolumn{6}{|c|}{ Protein } \\
\hline Intercept & $20,792.66$ & 1 & $20,792.66$ & $88,921.99$ & 0.000000 \\
\hline Number of applications & 0.39 & 1 & 0.39 & 1.65 & 0.206357 \\
\hline Treatment & 31.28 & 3 & 10.43 & 44.59 & 0.000000 \\
\hline Number of applications $\times$ treatment & 2.36 & 3 & 0.79 & 3.37 & 0.027788 \\
\hline Error & 9.35 & 40 & 0.23 & & \\
\hline \multicolumn{6}{|c|}{ Total phenols } \\
\hline Intercept & 731.7033 & 1 & 731.7033 & 3095.779 & 0.000000 \\
\hline Number of applications & 1.3763 & 1 & 1.3763 & 5.823 & 0.020490 \\
\hline Treatment & 6.8737 & 3 & 2.2912 & 9.694 & 0.000062 \\
\hline Number of applications $\times$ treatment & 2.5409 & 3 & 0.8470 & 3.583 & 0.021918 \\
\hline Error & 9.4542 & 40 & 0.2364 & & \\
\hline \multicolumn{6}{|c|}{ Total flavonoids } \\
\hline Intercept & 0.159506 & 1 & 0.159506 & 7312.597 & 0.000000 \\
\hline Number of applications & 0.000001 & 1 & 0.000001 & 0.024 & 0.877973 \\
\hline Treatment & 0.006708 & 3 & 0.002236 & 102.506 & 0.000000 \\
\hline Number of applications $\times$ treatment & 0.000174 & 3 & 0.000058 & 2.663 & 0.060961 \\
\hline Error & 0.000873 & 40 & 0.000022 & & \\
\hline
\end{tabular}

Number of applications (1 or 2); treatment (Fylloton; Terra Sorb Complex, Kelpak, control). 
Treating plants with the biostimulants had a positive effect on increasing the number of pods (Table 4). In 2015, no significant effect of the biostimulants on the studied trait was identified; however, a tendency to increase the number of pods was observed after foliar application of biostimulants, especially Kelpak. On the other hand, in 2016, after treating the plants with biostimulants based on seaweed extract, i.e., both after a single application of Kelpak (Ecklonia maxima extract) and after a single or double application of Fylloton (Ascophyllum nodosum extract, amino acids), a significant increase in this trait was identified (increases by 36\%, 28\%, and 33\%, respectively, as compared to the control). Treatment of plants with Kelpak in 2017 significantly increased the number of pods, regardless of the number of applications (increase by $18 \%$ for a single application, and by $19 \%$ for a double application, as compared to the control). A synthesis of the three years of research (2015-2017) confirmed that a single spraying of plants with the Kelpak biostimulant in the BBCH 12-13 phase significantly increased the number of pods (by $26 \%$ ), as compared to the control.

Table 4. Effect of Fylloton, Terra Sorb Complex, and Kelpak biostimulants treatment on number of pods and seeds of bean variety Oczko.

\begin{tabular}{cccccc}
\hline \multirow{2}{*}{ Parameters } & $\begin{array}{c}\text { Biostimulant } \\
\text { Treatment }\end{array}$ & \multicolumn{3}{c}{ Season } & $\begin{array}{c}\text { Average } \\
\text { 2015-2017 }\end{array}$ \\
\cline { 3 - 5 } & F_1 & $224 \pm 7.8$ n.s. & $240 \pm 8.5 \mathrm{a}$ & $231 \pm 11.3 \mathrm{ab}$ & $232 \pm 4.0 \mathrm{~b}$ \\
& F_2 & $234 \pm 9.9$ n.s. & $249 \pm 8.5 \mathrm{a}$ & $245 \pm 4.9 \mathrm{ab}$ & $243 \pm 7.8 \mathrm{ab}$ \\
Number of & TS_1 & $223 \pm 29.7$ n.s. & $207 \pm 7.8 \mathrm{bc}$ & $249 \pm 7.8 \mathrm{ab}$ & $226 \pm 4.7 \mathrm{~b}$ \\
pods & TS_2 & $248 \pm 12.0$ n.s. & $234 \pm 9.9 \mathrm{ab}$ & $254 \pm 9.8 \mathrm{ab}$ & $245 \pm 2.6 \mathrm{ab}$ \\
$\left(\right.$ per m $\left.{ }^{2}\right)$ & K_1 & $257 \pm 10.6$ n.s. & $254 \pm 7.8 \mathrm{a}$ & $258 \pm 12.0 \mathrm{a}$ & $256 \pm 3.1 \mathrm{a}$ \\
& K_2 & $252 \pm 18.4$ n.s. & $225 \pm 6.4 \mathrm{ab}$ & $260 \pm 6.3 \mathrm{a}$ & $245 \pm 6.1 \mathrm{ab}$ \\
& C & $203 \pm 17.7$ n.s. & $187 \pm 9.2 \mathrm{c}$ & $219 \pm 9.2 \mathrm{~b}$ & $203 \pm 5.9 \mathrm{c}$ \\
\hline \multirow{2}{*}{ Number of } & F_1 & $776 \pm 9.2 \mathrm{a}$ & $649 \pm 9.2 \mathrm{~d}$ & $686 \pm 24.0 \mathrm{bc}$ & $703 \pm 1.9 \mathrm{c}$ \\
seeds & F_2 & $809 \pm 17.0 \mathrm{a}$ & $774 \pm 17.7 \mathrm{~b}$ & $799 \pm 23.3 \mathrm{a}$ & $794 \pm 3.8 \mathrm{a}$ \\
$($ TS_1 & $713 \pm 19.1 \mathrm{~b}$ & $720 \pm 4.9 \mathrm{c}$ & $693 \pm 21.9 \mathrm{bc}$ & $708 \pm 2.6 \mathrm{c}$ \\
& TS_2 & $762 \pm 6.4 \mathrm{ab}$ & $752 \pm 6.4 \mathrm{bc}$ & $751 \pm 21.8 \mathrm{ab}$ & $755 \pm 3.1 \mathrm{~b}$ \\
& K_1 & $764 \pm 22.6 \mathrm{ab}$ & $777 \pm 9.9 \mathrm{~b}$ & $754 \pm 20.5 \mathrm{ab}$ & $765 \pm 2.6 \mathrm{~b}$ \\
& K_2 & $793 \pm 15.6 \mathrm{a}$ & $835 \pm 5.7 \mathrm{a}$ & $780 \pm 25.5 \mathrm{a}$ & $803 \pm 5.2 \mathrm{a}$ \\
& C & $602 \pm 14.8 \mathrm{c}$ & $611 \pm 19.1 \mathrm{~d}$ & $613 \pm 5.7 \mathrm{c}$ & $608 \pm 9.4 \mathrm{~d}$ \\
\hline
\end{tabular}

Abbreviations: F_1, single spraying of Fylloton; F_2, double spraying of Fylloton; TS_1, single spraying of Terra Sorb Complex; TS_2, double spraying of Terra Sorb Complex; K_1, single spraying of Kelpak; K_2, double spraying of Kelpak; C, control; n.s., not significant. Means in the columns, concerning the selected traits, followed by different small letters are significantly different at $p<0.05$.

Analysis of variance showed that, regardless of the number of applications, the treatment of plants with Fylloton significantly increased the number of seeds in 2015, as did the double spraying with Kelpak (increases by 29\%, 34\%, and 32\% respectively, as compared to the control) (Table 4 ). In the second year of research, the best results were obtained after double spraying with biostimulant based on the extract of Ecklonia maxima, with a significant increase of $37 \%$, as compared to the control. In 2017, it was found that spraying plants with biostimulants containing seaweed extracts, i.e., Fylloton and Kelpak, significantly increased the number of seeds, by $30 \%$ and $27 \%$, respectively, as compared to the control. The average of three years of research demonstrated that an increase of this trait, by $31 \%$ and $32 \%$, respectively, as compared to the control, was obtained after a double foliar application of Fylloton and Kelpak.

Double application of Kelpak, in 2015 and 2016, had the most beneficial effect on seed yield, increasing this trait by $22 \%$ and $38 \%$, respectively, as compared to the control (Figure 1). In 2017, the best effects in increasing the bean crop were obtained after double treatment of plants with Fylloton and Kelpak biostimulants, when a $25 \%$ increase of this trait was obtained, as compared to the control. A synthesis of the three years of research demonstrated that double spraying plants with Kelpak 
biostimulant was most beneficial for increasing the bean yield (increase by $28 \%$ as compared to the control).

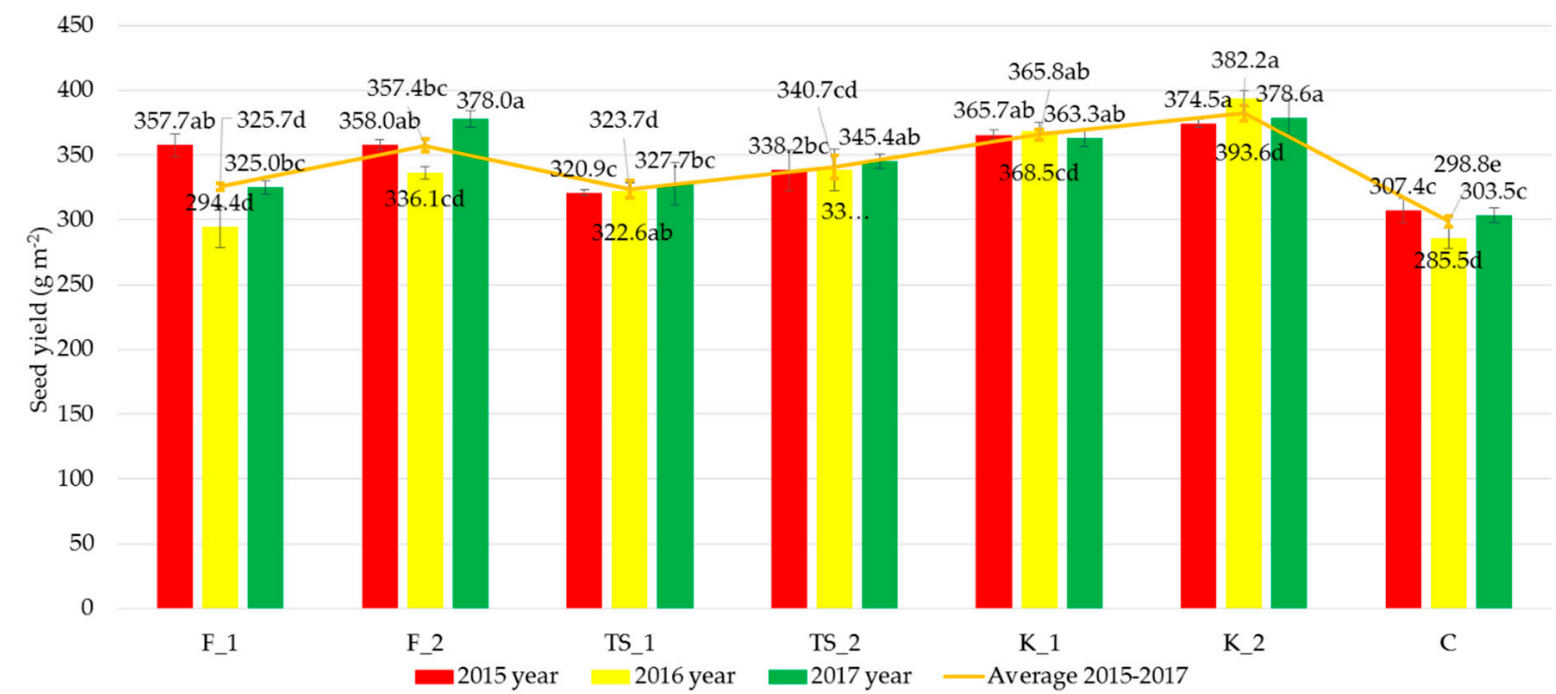

Figure 1. Effect of Fylloton, Terra Sorb Complex, and Kelpak biostimulant treatment on seed yield of bean variety Oczko. Abbreviations: F_1, single spraying of Fylloton; F_2, double spraying of Fylloton; TS_1, single spraying of Terra Sorb Complex; TS_2, double spraying of Terra Sorb Complex; K_1, single spraying of Kelpak; K_2, double spraying of Kelpak; C, control. Means over the study years followed by different small letters are significantly different at $p<0.05$.

Analysis of variance showed that the use of biostimulants in bean cultivation resulted in a reduction of the weight of one thousand seeds (Figure 2). In the first year of research, a significant increase in the weight of one thousand seeds was obtained in the control, by $11 \%-15 \%$, as compared to the combination with Fylloton or Terra Sorb Complex. However, in 2016 there were no significant differences in the weight of one thousand seeds between the combinations that included the biostimulants and the control. Plants in the control plot in 2017 were characterized by a higher weight of one thousand seeds by $8 \%$, as compared to the double application of the Terra Sorb Complex. In turn, the average of three years of research confirmed that the highest weight of one thousand seeds (an increase of $9 \%$, as compared to the double use of Fylloton) was obtained in the control.

Foliar application of biostimulants increased the protein content in the seeds (Table 5). In 2015 and 2017, the best effects were obtained after applying Terra Sorb Complex as a single or double spraying of plants, which increased this trait by $12 \%$ and 13\% (in 2015), and by $9 \%$ and $10 \%$ (in 2017), respectively, as compared to the control. Double treatment of plants with the Terra Sorb Complex biostimulant in 2016 had the most beneficial effect on increasing the protein content by $13 \%$, as compared to the control. A synthesis of the three years of research showed that, regardless of the number of applications, the use of an amino acid-based biostimulant significantly increased the protein content, as did the double application of the biostimulant containing the of the Ecklonia maxima extract (11\%, 12\%, and 10\% increases, respectively, as compared to the control). 


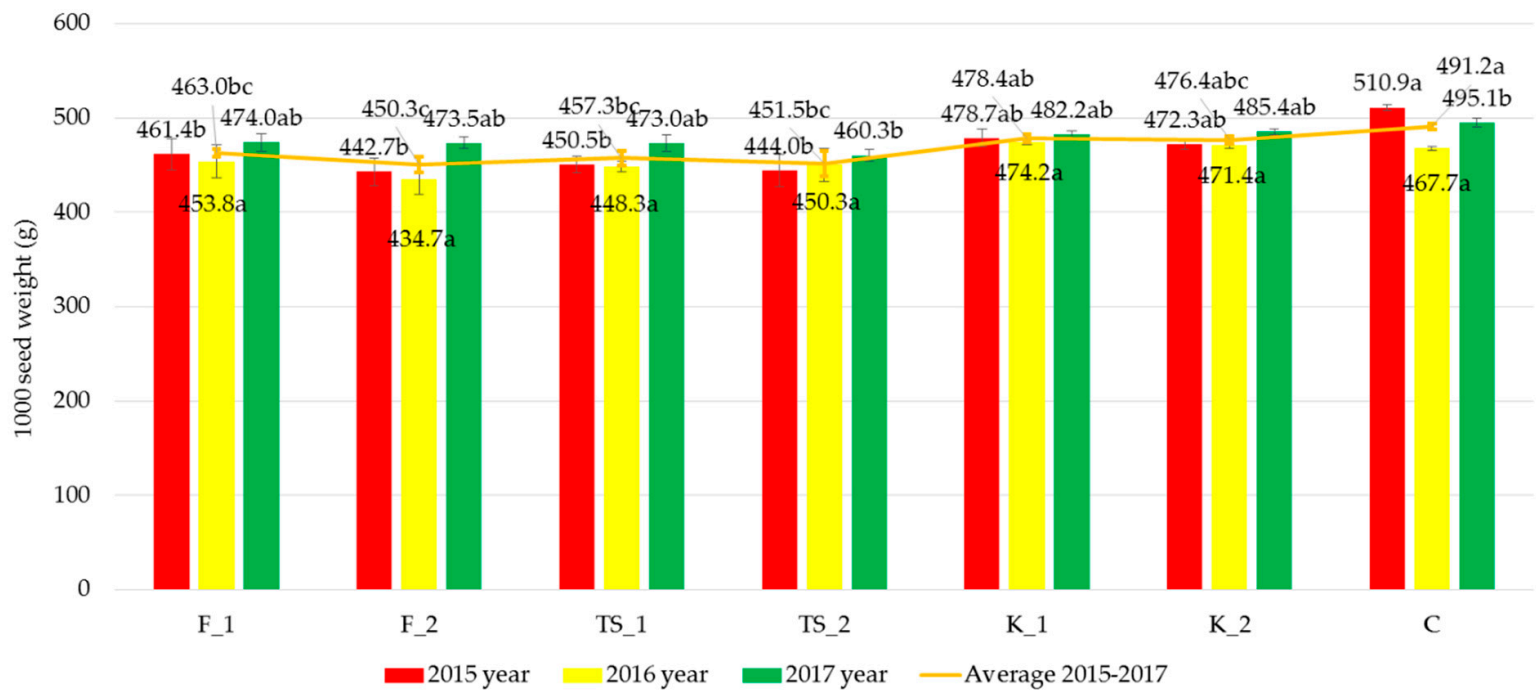

Figure 2. Effect of Fylloton, Terra Sorb Complex, and Kelpak biostimulant treatment on the weight of one thousand seeds of bean variety Oczko. Abbreviations: F_1, single spraying of Fylloton; F_2, double spraying of Fylloton; TS_1, single spraying of Terra Sorb Complex; TS_2, double spraying of Terra Sorb Complex; K_1, single spraying of Kelpak; K_2, double spraying of Kelpak; C, control. Means over the study years followed by different small letters are significantly different at $p<0.05$.

Table 5. Effect of Fylloton, Terra Sorb Complex, and Kelpak biostimulant treatment on protein, phenol, and flavonoid content of bean seeds.

\begin{tabular}{cccccc}
\hline \multirow{2}{*}{ Parameters } & Biostimulant & \multicolumn{3}{c}{ Season } & Average \\
& Treatment & $\mathbf{2 0 1 5}$ & $\mathbf{2 0 1 6}$ & $\mathbf{2 0 1 7}$ & 2015-2017 \\
\cline { 3 - 5 } & F_1 & $21.19 \pm 0.23 \mathrm{bc}$ & $20.59 \pm 0.29 \mathrm{bc}$ & $21.30 \pm 0.14 \mathrm{ab}$ & $21.03 \pm 0.38 \mathrm{a}$ \\
& F_2 & $20.82 \pm 0.10 \mathrm{c}$ & $20.19 \pm 0.14 \mathrm{c}$ & $21.01 \pm 0.10 \mathrm{ab}$ & $20.67 \pm 0.60 \mathrm{ab}$ \\
Protein & TS_1 & $21.81 \pm 0.02 \mathrm{a}$ & $21.20 \pm 0.05 \mathrm{ab}$ & $22.04 \pm 0.02 \mathrm{a}$ & $21.68 \pm 0.43 \mathrm{a}$ \\
& TS_2 & $21.99 \pm 0.04 \mathrm{a}$ & $21.38 \pm 0.10 \mathrm{a}$ & $22.27 \pm 0.18 \mathrm{a}$ & $21.88 \pm 0.46 \mathrm{a}$ \\
& K_1 & $20.74 \pm 0.27 \mathrm{c}$ & $20.05 \pm 0.27 \mathrm{c}$ & $21.14 \pm 0.43 \mathrm{ab}$ & $20.64 \pm 0.55 \mathrm{ab}$ \\
& K_2 & $21.79 \pm 0.08 \mathrm{ab}$ & $21.15 \pm 0.16 \mathrm{ab}$ & $21.61 \pm 0.59 \mathrm{ab}$ & $21.52 \pm 0.33 \mathrm{a}$ \\
& C & $19.53 \pm 0.15 \mathrm{~d}$ & $18.94 \pm 0.17 \mathrm{~d}$ & $20.18 \pm 0.58 \mathrm{~b}$ & $19.55 \pm 0.62 \mathrm{~b}$ \\
\hline & F_1 & $3.76 \pm 0.0 \mathrm{~b}$ & $4.02 \pm 0.02 \mathrm{c}$ & $4.13 \pm 0.03 \mathrm{c}$ & $3.97 \pm 0.19 \mathrm{n} . s$. \\
Total phenols & F_2 & $5.96 \pm 0.05 \mathrm{a}$ & $3.56 \pm 0.01 \mathrm{~d}$ & $4.11 \pm 0.02 \mathrm{c}$ & $4.54 \pm 1.29 \mathrm{n} . s$. \\
(mg.g ${ }^{-1}$ DM) & TS_1 & $4.01 \pm 0.01 \mathrm{~b}$ & $4.43 \pm 0.01 \mathrm{~b}$ & $4.36 \pm 0.03 \mathrm{~b}$ & $4.26 \pm 0.22 \mathrm{n} . \mathrm{s}$. \\
& TS_2 & $4.01 \pm 0.03 \mathrm{~b}$ & $4.48 \pm 0.12 \mathrm{ab}$ & $3.74 \pm 0.06 \mathrm{~d}$ & $4.07 \pm 0.37 \mathrm{n} . s$. \\
& K_1 & $2.82 \pm 0.22 \mathrm{~d}$ & $3.89 \pm 0.09 \mathrm{c}$ & $3.54 \pm 0.08 \mathrm{e}$ & $3.42 \pm 0.54 \mathrm{n} . s$. \\
& K_2 & $3.83 \pm 0.01 \mathrm{~b}$ & $4.70 \pm 0.04 \mathrm{a}$ & $4.63 \pm 0.04 \mathrm{a}$ & $4.39 \pm 0.48 \mathrm{n} . \mathrm{s}$. \\
& C & $3.27 \pm 0.08 \mathrm{c}$ & $3.30 \pm 0.05 \mathrm{e}$ & $3.29 \pm 0.01 \mathrm{f}$ & $3.29 \pm 0.02 \mathrm{n} . \mathrm{s}$. \\
\hline & F_1 & $0.061 \pm 0.001 \mathrm{bc}$ & $0.075 \pm 0.001 \mathrm{a}$ & $0.078 \pm 0.001 \mathrm{a}$ & $0.071 \pm 0.009 \mathrm{a}$ \\
Total & F_2 & $0.058 \pm 0.001 \mathrm{c}$ & $0.066 \pm 0.001 \mathrm{ab}$ & $0.068 \pm 0.001 \mathrm{~b}$ & $0.064 \pm 0.005 \mathrm{a}$ \\
flavonoids & TS_1 & $0.059 \pm 0.001 \mathrm{c}$ & $0.060 \pm 0.008 \mathrm{~b}$ & $0.069 \pm 0.001 \mathrm{~b}$ & $0.063 \pm 0.006 \mathrm{a}$ \\
(mg.g ${ }^{-1}$ DM) & TS_2 & $0.063 \pm 0.001 \mathrm{ab}$ & $0.061 \pm 0.001 \mathrm{ab}$ & $0.065 \pm 0.001 \mathrm{~b}$ & $0.063 \pm 0.002 \mathrm{a}$ \\
& K_1 & $0.064 \pm 0.002 \mathrm{ab}$ & $0.062 \pm 0.003 \mathrm{ab}$ & $0.066 \pm 0.001 \mathrm{~b}$ & $0.064 \pm 0.002 \mathrm{a}$ \\
& K_2 & $0.067 \pm 0.001 \mathrm{a}$ & $0.073 \pm 0.001 \mathrm{ab}$ & $0.075 \pm 0.001 \mathrm{a}$ & $0.072 \pm 0.004 \mathrm{a}$ \\
& C & $0.036 \pm 0.001 \mathrm{~d}$ & $0.038 \pm 0.001 \mathrm{c}$ & $0.041 \pm 0.001 \mathrm{c}$ & $0.038 \pm 0.003 \mathrm{~b}$ \\
\hline
\end{tabular}

Abbreviation: F_1, single spraying of Fylloton; F_2, double spraying of Fylloton; TS_1, single spraying of Terra Sorb Complex; TS_2, double spraying of Terra Sorb Complex; K_1, single spraying of Kelpak; K_2, double spraying of Kelpak; C, control; n.s., not significant; DM, dry matter. Means in the columns, concerning the selected traits, followed by different small letters are significantly different at $p<0.05$.

Double application of biostimulants containing seaweed extracts most favorably impacted the content of phenols in the seeds (Table 5). In 2015, an increase in the phenolic compound content in 
beans was noted after a double application of Fylloton (an increase of this trait by $82 \%$, as compared to the control). However, after a single application of Kelpak, this trait was found to be reduced, as compared to the control. In turn, in 2016 and 2017, the best effects in increasing the phenol content were observed after a double application of Kelpak (increases by $42 \%$ and $41 \%$, respectively, as compared to the control). No significant differences were found for this trait in the average for the years 2015-2017, but only a tendency to increase after a double application of biostimulants containing seaweed.

The application of preparations containing seaweed had the most beneficial effect on increasing the flavonoid content in the seeds (Table 5). In the first year of research, this characteristic was increased by $87 \%$, as compared to the control, after a double application of Kelpak. In 2016, a single application of Fylloton had the most beneficial effect on the increase of the flavonoid content (by $98 \%$, as compared to the control). On the other hand, in 2017, a significant increase in the flavonoid content was noted both with a single application of Fylloton and double of Kelpak (increases by $90 \%$ and $82 \%$, respectively, as compared to the control). The average of three years of research showed that the application of all biostimulants significantly increased the flavonoid content, by $64 \%-88 \%$, as compared to the control.

\section{Discussion}

The results of our research show a positive effect of natural biostimulants on bean yield, as well as on its quality. A more beneficial effect in modifying the yield components (number of pods and seeds, seed yield) was obtained after using biostimulants based on seaweed extract, especially upon double application of the Ecklonia maxima (Kelpak) extract. Only in the case of the weight of one thousand seeds was a reduction of this trait observed as a result of using biostimulants. The use of other biostimulants, i.e., Fylloton, which contains an Ascophyllum nodosum extract and amino acids, as well as Terra Sorb Complex containing amino acids, also had a positive effect on the yield components. In turn, the conditions favorable for setting pods and seeds, and increasing the weight of seeds were the most beneficial in 2016, when the double use of Kelpak resulted in the largest increase in these characteristics compared to control. This year, there were also favorable temperature and humidity conditions conducive to flowering, and setting pods and seeds. The significant increase in protein content was most positively influenced by weather conditions in 2015 and 2016, when the highest value of this feature was obtained after double application of Terra Sorb Complex. The application of biostimulants based on marine algae had a positive effect on the flavonoid content in all years of research. In 2015, however, a significant increase in polyphenols was found after double application of Fylloton.

Numerous studies conducted on arable crops confirmed the beneficial effect of seaweed extracts on increasing yield components $[11,12,47,64-66]$. Previous research on other bean and soybean varieties confirmed the stimulating effect of the Ecklonia maxima or Ascophyllum nodosum extracts on the number of pods and seeds, and the weight of beans [39-41,67]. The lack of effect of Kelpak on the one-thousand-seed weight of bean was also confirmed by previous studies on common bean [66]. Use of extracts from Kappaphycus alvarezii and A. nodosum increased the number of pods, seeds, and yield in soybean [68,69], even under stress conditions (reduced NPK fertilization) [70]. Bean plants reacted favorably to the foliar application of Caulerpa racemosa and A. nodosum extract by increasing the number of pods and seeds, one thousand weight of bean, and seed yield in common beans [71,72], mung beans [73], and broad beans [74].

The foliar application of amino acids positively affects the yield of many plants, even growing under stress $[11,75,76]$. In previous studies, the studied bean responded positively to foliar application of the Terra Sorb Complex; however, the yielding effect depended on the variety, concentration, and number of applications of the biostimulant, as well as climatic conditions prevailing in a given study year [59]. The Aura variety (with white seeds) responded more favorably to a single application of a $0.5 \%$ concentration, and the Toska variety (with red seeds) responded more favorably to a single application of a $0.3 \%$ concentration of this biostimulant. The plants increased the number of pods and seeds, as well as the seed yield; however, no effect of this biostimulant was found for the weight of one 
thousand seeds. Foliar application of biostimulants containing amino acids increased the number of pods and seeds, weight of one thousand seeds, and yield in seeds of beans [71,77], peas [78], and broad beans $[79,80]$.

The positive effect of seaweed extracts on plant growth and development and, as a result, on the increase in yield is undoubtedly associated with the presence of phytohormones, especially cytokinins [81]. Together with auxins, cytokinins regulate many physiological processes, including those affecting plant growth and development [82-84]. Aremu et al. [85] and Masondo et al. [86] also observed a positive effect of Kelpak on increasing the content of cytokinins. In addition, Kulkarni et al. [87] found an increase in the content of cis-zeatin, dihydrozeatin, and isopentenyladenine after using the Ecklonia maxima extract (Kelpak). The many active substances and compounds included in Kelpak suggest that it is not only cytokinin that is responsible for the growth and development of plants, but also probably the cross-reactions of these compounds with other bioactive molecules included in biostimulants that are based on seaweed extracts [70].

Thanks to the content of endogenous auxins, seaweed extracts have a positive effect on the growth and development of the root system [88]. This improves the uptake of water and nutrients and, in effect, stimulates the growth and development of plants, contributing to the improvement of yield quantity and quality [81]. The application of biostimulants based on seaweed extracts also has a positive effect on plant growth and development due to the content of gibberellins (GA1, GA3, GA4, GA5, GA6, GA7, GA13) [14], which affect seed germination, stem elongation, leaf expansion, and flower and seed development [89-91], as well as of gibberellin-like substances, e.g., terpenoids and tocopherol [92,93]. In the seaweed extract (Kelpak), the presence of brassinosteroids, brassinolide and castasterone [10], was identified. As phytohormones, brassinosteroids promote cell division and elongation, stimulate stem and root growth, and initiate flowering and flower development, as well as fruit development and increases in seed yield. Under stress conditions, they protect plants against abiotic and biotic stress [94,95].

The positive effect of amino acid-based preparations on plant growth and development probably results from the fact that, at the molecular level, they stimulate the plant's defense response to biotic and abiotic stress factors [96]. The amino acids contained in them are easily absorbed by plants. They participate in the synthesis of a number of organic compounds and affect the uptake of macro- and microelements [97]. Garcia et al. [98] showed that foliar application of amino acids and peptides together with nutrients increases the content of potassium, calcium, magnesium, iron, copper, and zinc in leaves, affecting their nutritional condition and promoting improved growth and development of plants. Applied on a leaf, preparations of this type exhibit phytohormone-like effects, comparable to that of auxin and gibberellin [54]. They also contribute to increasing the content of phytohormones (gibberellins, cytokinins, auxins) [76]. In addition, the use of protein hydrolysates in plant cultivation has a beneficial effect on the uptake of water and nutrients, resulting in increasing crop yielding thanks to the increased microbial and enzymatic activity of the soil, improved mobility and solubility of microelements (iron, zinc, manganese, copper), modified structure of the root system (its length, compaction, and number of lateral roots), or the increased synthesis of nitrate and glutamine reductase, as well as the activity of iron reductase [11,54,99-102]. Numerous reports confirmed that protein hydrolysates, such as auxins and gibberellins, have hormone-like effects, stimulating root and shoot growth. This, in turn, has a positive effect on crop productivity [11,53,54,100,102-106].

In our research, the use of biostimulants based on amino acids and seaweed extracts had a positive effect on the nutritional value of beans by increasing their protein content. Application of seaweed extract and amino acids had a positive effect on increasing the protein content in bean, pea, and faba bean seeds $[59,71,74,78,80]$. This was confirmed by Rouphael [62]; in their research, the increase in protein content in spinach plants was obtained after using biostimulants containing an extract of Ecklonia maxima and Ascophyllum nodosum and legume-derived protein hydrolysate. The protein content of legumes leaves was also determined by seaweed extracts. Numerous authors found an increase in this trait after the application of Ulva rigida, Fucus spiralis, Hypnea musciformis, and 
Colpomenia sinuosa extracts in bean leaves $[16,107,108]$. However, the use of biostimulants is not always beneficial for the protein content in beans [15,109]. Schubert and Mengel [110] demonstrated that amino-acid uptake is an important mechanism for recovering carbon and nitrogen that was lost in the rhizosphere. Ertani et al. [100] found that the stimulation of nitrogen assimilation is responsible for accelerating the growth and metabolism of nitrogen in plants treated with protein hydrolysates. This is due to an increase in the activity of two key enzymes, nitrate reductase and glutamine synthetase, thereby contributing to increasing protein firmness.

After the application of biostimulants containing seaweed extracts, researchers observed an increase in the phenolic content. Ertani [56] showed that the treatment of plants with biostimulants stimulates numerous metabolic pathways in plants. The pathways are also associated with the synthesis of secondary metabolites, including phenolic compounds, which play an important role in protecting plants against stress factors. In turn, a frequent indicator of plant resistance to biotic factors is the content of phenolic compounds, which are precursors to more complex phenolic structures, such as flavonoids and lignins $[60,111]$. The presence of bioactive compounds in biostimulants, including phytohormones, amino acids, protein, and phenols, is responsible for the physiological response of plants treated with these preparations $[56,112,113]$. Eckol (phenolic compound) found in seaweed extracts affects the phenylpropanoid pathway in the biochemical synthesis of phenolic acids [114]. Aremu et al. [85,115] showed that the timing of eckol plants increases the content of phenolic compounds, such as $p$-hydroxybenzoic and ferulic acids. In turn, the Kelpak application increases the content of caffeic acid, ferulic acid [85,116], protocatechuic acid, $p$-hydroxybenzoic acid, gentisic acid, $p$-coumaric acid, and trans-cinnamic acid in Eucomis autumnalis [85]; however, the content of phenolic compounds depended on the biostimulant concentration. In turn, Rouphael et al. [62] found an increased content of phenolic compounds after the treatment of plants with biostimulants containing alginians, fucoidans, and laminarins that affect endogenic hormonal homeostasis [117]. Treatment of plants with eckol also had a positive effect on the flavonoid content, increasing the amount of kempferol in plants several times. However, foliar application of Kelpak increased the content of kaempferol in tubers and entire plants, as well as taxifolin in leaves of Eucomis autumnalis [85,115]. Increasing the content of bioactive compounds in plants treated with biostimulants is associated with a mechanism that includes the stimulation of the chalcone isomerase enzyme, involved in the biosynthesis of flavanone precursors [117].

Paul et al. [118] found that tomato plants treated with protein hydrolysates were characterized by a higher content of, e.g., low-molecular-weight phenolic compounds, phytohormones (polyamines), hydroxy-carotenoids, poly-hydroxy fatty acids, and membrane lipids (glycoand phospholipids). They suggest that the metabolic changes caused by treating plants with protein hydrolysates can be correlated with a relatively small number of processes that converge toward the ROS-related (reactive oxygen species-related) plant signaling network. Increasing the content of secondary metabolites, such as phenols and carotenoids, which play a key role in protecting plants against oxidative stress [62,102,119], suggests fine-tuning of ROS signaling in plants after the application of protein hydrolysates [118]. In addition, the use of animal protein hydrolysates had a positive effect on the content of protein, phenols, and flavonoids in bananas [120], and vegetal protein hydrolysates stimulated an increase in the content of phenolic compounds and anthocyanins in grape [55].

So far, there are few reports confirming the beneficial effect of a preparation consisting of a combination of seaweed extract and amino acids. In our research, combining the Fylloton biostimulant, which induces the extract's effect, with Ascophyllum nodosum and amino acids increased the yield components, particularly the number of seeds after its double application. Moreover, previous studies, conducted on three soybean varieties, confirmed that this preparation has a positive effect on the number of pods and seeds, as well as seed yield [40]. The application of Fylloton in the cultivation of winter oilseed rape positively influenced the increase in the number of pods, the yield of seeds, and the weight of one thousand seeds, especially after applying the biostimulant together 
with the Perfektmikro micronutrient fertilizer containing EDTA-chelated (ethylenediaminetetraacetic acid-chelated) manganese, copper, iron, and zinc, as well as molybdenum, boron, and nitrogen [121].

\section{Conclusions}

All studied biostimulants had a positive effect on quantity and quality of bean yield. Double application of Kelpak biostimulant (Ecklonia maxima extract) stimulated morphological features and seed yield, as well as the content of polyphenols and flavonoids in seeds to a greater extent. In turn, the biostimulant containing amino acids (Terra Sorb Complex) significantly increased the protein content in beans. In contrast, Fylloton containing Ascophyllum nodosum extract and amino acids had also a more favorable effect on the number of seeds. In 2015 and 2017, biostimulants containing seaweed extracts had the most beneficial effect on bean yield and its quality. On the other hand, in 2016, treatment of plants with Kelpak had a more beneficial effect on the studied features.

Author Contributions: All authors read and agreed to the published version of the manuscript. A.K. and J.L. conceptualized and designed the research; R.K. and M.T. performed the field experiments; J.L, N.N., and K.K. analyzed the plant material; S.T. carried out statistical analysis of the data; A.K., R.K., and D.L. wrote the paper; M.T. and S.T. revised the manuscript.

Funding: This research received no external funding.

Conflicts of Interest: The authors declare no conflicts of interest.

\section{References}

1. Caruso, G.; De Pascale, S.; Cozzolino, E.; Cuciniello, A.; Cenvinzo, V.; Bonini, P.; Colla, G.; Rouphael, Y. Yield and nutritional quality of Vesuvian Piennolo tomato PDO as affected by farming system and biostimulant application. Agronomy 2019, 9, 505. [CrossRef]

2. Caruso, G.; De Pascale, S.; Cozzolino, E.; Giordano, M.; El-Nakhel, C.; Cuciniello, A.; Cenvinzo, V.; Colla, G.; Rouphael, Y. Protein hydrolysate or plant extract-based biostimulants enhanced yield and quality performances of greenhouse perennial wall rocket grown in different seasons. Plants 2019, 8, 208. [CrossRef] [PubMed]

3. Du Jardin, P. Plant biostimulants: Definition, concept, main categories and regulation. Sci. Hortic. 2015, 196, 3-14. [CrossRef]

4. Matyjaszczyk, E. The introduction of biostimulants on the Polish market. The present situation and legal requirements. Przem. Chem. 2015, 10, 1841-1844. [CrossRef]

5. Matyjaszczyk, E. Problems of implementing compulsory integrated pest management. Pest. Manag. Sci. 2019, 75, 2063-2067. [CrossRef]

6. Traon, D.; Amat, L.; Zotz, F.; Du Jardin, P. A Legal Framework for Plant Biostimulants and Agronomic Fertiliser Additives in the EU. Report for the European Commission Enterprise E Industry Directorate-General; Publications Office of the European Union: Luxembourg, 2014.

7. Matyjaszczyk, E. "Biorationals" in integrated pest management strategies. J. Plant Dis. Prot. 2018, 125, 523-527. [CrossRef]

8. Calvo, P.; Nelson, L.; Kloepper, J.W. Agricultural uses of plant biostimulants. Plant Soil 2014, 383, 3-41. [CrossRef]

9. Rouphael, Y.; Cardarelli, M.; Bonini, P.; Colla, G. Synergistic action of a microbial-based biostimulant and a plant derived-protein hydrolysate enhances lettuce tolerance to alkalinity and salinity. Front. Plant Sci. 2017, 8, 131. [CrossRef]

10. Colla, G.; Rouphael, Y. Biostimulants in horticulture. Sci. Hortic. 2015, 196, 1-2. [CrossRef]

11. Colla, G.; Hoagland, L.; Ruzzi, M.; Cardarelli, M.; Bonini, P.; Canaguier, R.; Rouphael, Y. Biostimulant action of protein hydrolysates: unraveling their effects on plant physiology and microbiome. Front. Plant Sci. 2017, 8, 2202. [CrossRef]

12. Battacharyya, D.; Babgohari, M.Z.; Rathor, P.; Prithiviraj, B. Seaweed extracts as biostimulants in horticulture. Sci. Hortic. 2015, 196, 39-48. [CrossRef]

13. Basak, A. Biostimulators. Definitions, classification and legislation. In Biostimulators in Modern Agriculture, General Aspects; Gawrońska, H., Ed.; Editorial House Wieś Jutra: Warszawa, Poland, 2008; pp. 7-17. 
14. Stirk, W.A.; Tarkowská, D.; Turecová, V.; Strnad, M.; van Staden, J. Abscisic acid, gibberellins and brassinosteroids in Kelpak ${ }^{\circledR}$, a commercial seaweed extract made from Ecklonia maxima. J. Appl. Phycol. 2014, 26, 561-567. [CrossRef]

15. Kocira, A.; Świeca, M.; Kocira, S.; Złotek, U.; Jakubczyk, A. Enhancement of yield, nutritional and nutraceutical properties of two common bean cultivars following the application of seaweed extract (Ecklonia maxima). Saudi J. Biol. Sci. 2018, 25, 563-571. [CrossRef]

16. Latique, S.; Chernane, H.; Mansori, M.; El Kaoua, M. Seaweed liquid fertilizer effect on physiological and biochemical parameters of bean plant (Phaesolus vulgaris variety Paulista) under hydroponic system. Eu. Sci. J. 2013, 9, 174-191.

17. Sharma, S.H.S.; Lyons, G.; McRoberts, C.; McCall, D.; Carmichael, E.; Andrews, F.; Swan, R.; McCormack, R.; Mellon, R. Biostimulant activity of brown seaweed species from Strangford Lough: compositional analyses of polysaccharides and bioassay of extracts using mung bean (Vigno mungo L.) and pak choi (Brassica rapa chinensis L.). J. Appl. Phycol. 2012, 24, 1081-1091. [CrossRef]

18. Stirk, W.A.; Van Standen, J. Flow of cytokinins through the environment. Plant. Growth Regul. 2010, 62, 101-116. [CrossRef]

19. Tarakhovskaya, E.R.; Maslov, Y.I.; Shishova, M.F. Phytohormones in algae. Russ. J. Plant. Physiol. 2007, 54, 163-170. [CrossRef]

20. Klarzynski, O.; Descamps, V.; Plesse, B.; Yvin, J.C.; Fritig, B. Sulfated fucan oligosaccharides elicit defense responses in tobacco and local and systemic resistance against Tobacco Mosaic Virus. Mol. Plant-Microbe Interact. 2003, 16, 115-122. [CrossRef]

21. Zhang, Q.; Zhang, J.; Shen, J.; Silva, A.; Dennis, D.A. A simple 96-well microplate method for estimation of total polyphenol content in seaweeds. J. Appl. Phycol. 2006, 18, 445-450. [CrossRef]

22. Rioux, L.E.; Turgeon, S.L.; Beaulieu, M. Characterization of polysaccharides extracted from brown seaweeds. Carbohydr. Polym. 2007, 69, 530-537. [CrossRef]

23. Stirk, W.A.; Novak, O.; Hrandecka, V.; Pencik, A.; Rolcik, J.; Strnad, M.; Van Staden, J. Endogenous cytokinins, auxins and abscisic acid in Ulva fasciata (Chlorophyta) and Dictyota humifusa (Phaeophyta): towards understanding their biosynthesis and homoeostasis. Eur. J. Phycol. 2009, 44, 231-240. [CrossRef]

24. Yokoya, N.S.; Stirk, W.A.; Van Staden, J.; Novak, O.; Tureckova, V.; Pencik, A.; Strnad, M. Endogenous cytokinins, auxins, and abscisic acid in red algae from Brazil. J. Phycol. 2010, 46, 1198-1205. [CrossRef]

25. Matysiak, K.; Kaczmarek, S.; Leszczyńska, D. Influence of liquid seaweed extract of Ecklonia maxima on winter wheat cv Tonacja. J. Res. Appl. Agric. Engin. 2012, 57, 44-47.

26. Papenfus, H.B.; Stirk, W.A.; Finnie, J.F.; Van Staden, J. Seasonal variation in the polyamines of Ecklonia maxima. Botanica Marina 2012, 55, 539-546. [CrossRef]

27. Rengasamy, K.R.R.; Kulkarni, M.G.; Stirk, W.A.; Van Staden, J. Eckol—a new plant growth stimulant from the brown seaweed Ecklonia maxima. J. Appl. Phycol. 2015, 27, 581-587. [CrossRef]

28. Rengasamy, K.R.R.; Kulkarni, M.G.; Stirk, W.A.; Van Staden, J. Eckol improves growth, enzyme activities, and secondary metabolite content in maize (Zea mays cv. Border King). J. Plant Growth Regul. 2015, 34, 410-416. [CrossRef]

29. Panda, D.; Pramanik, K.; Nayak, B.R. Use of sea weed extracts as plant growth regulators for sustainable agriculture. Int. J. Bioresour. Stress Manag. 2012, 3, 404-411.

30. Crough, I.J.; Van Staden, J. Effect of seaweed concentrate on the establishment and yield of greenhouse tomato plants. J. Appl. Phycol. 1992, 4, 291-296. [CrossRef]

31. Stirk, W.A.; Bálint, P.; Tarkowská, D.; Strnad, M.; van Staden, J.; Ördög, V. Endogenous brassinosteroids in microalgae exposed to salt and low temperature stress, Eur. J. Phycol. 2018. [CrossRef]

32. Ecoforce, A. Extracto de Algas para Agricultura Ecológica-Fertilizantes Ecoforce. Available online: http: //fertilizantesecoforce.es/es/blog/index/list/cat/agricultura-ecologica/?p=19 (accessed on 1 December 2019).

33. Van Oosten, M.J.; Pepe, O.; De Pascale, S.; Silletti, S.; Maggio, A. The role of biostimulants and bioeffectors as alleviators of abiotic stress in crop plants. Technol. Agric. 2017, 4, 5. [CrossRef]

34. Sosnowski, J.; Malinowska, E.; Jankowski, K.; Redzik, P. Morpho-chemical diversity in Festuca pratensis and Lolium perenne depending on concentrations of Ecklonia maxima extract. Appl. Ecol. Env. Res. 2016, 14, 369-379. [CrossRef]

35. Drobek, M.; Frac, M.; Cybulska, J. Plant biostimulants: importance of the quality and yield of horticultural crops and the improvement of plant tolerance to abiotic stress-A review. Agronomy 2019, 9, 335. [CrossRef] 
36. Ali, N.; Farrell, A.; Ramsubhag, A.; Jayaraman, J. The effect of Ascophyllum nodosum extract on the growth, yield and fruit quality of tomato grown under tropical conditions. J. Appl. Phycol. 2016, 28, 1353-1362. [CrossRef]

37. Mikiciuk, M.; Dobromilska, R. Assessment of yield and physiological indices of small sized tomato cv. 'Bianka F1' under the influence of biostimulators of marine algae origin. Acta Sci. Pol., Hortorum Cultus 2014, 13, 31-41.

38. Chanthini, K.-P.; Stanley-Raja, V.; Thanigaivel, A.; Karthi, S.; Palanikani, R.; Shyam Sundar, N.; Sivanesh, H.; Soranam, R.; Senthil-Nathan, S. Sustainable agronomic strategies for enhancing the yield and nutritional quality of wild tomato, Solanum lycopersicum (l) var cerasiforme Mill. Agronomy 2019, 9, 311. [CrossRef]

39. Kocira, S.; Kocira, A.; Kornas, R.; Koszel, M.; Szmigielski, M.; Krajewska, M.; Szparaga, A.; Krzysiak, Z. Effect of seaweed extract on yield and protein content of two common bean (Phaseolus vulgaris L.) cultivars. Legume Res. 2017, LR-383. [CrossRef]

40. Kocira, S.; Szparaga, A.; Kocira, A.; Czerwińska, E.; Wójtowicz, A.; Bronowicka-Mielniczuk, U.; Koszel, M.; Findura, P. Modelling biometric traits, yield and nutritional and antioxidant properties of seeds of three soybean cultivars through the application of biostimulant containing seaweed and amino acids. Front. Plant Sci. 2018, 9. [CrossRef]

41. Kocira, S.; Szparaga, A.; Kuboń, M.; Czerwińska, E.; Piskier, T. Morphological and biochemical responses of Glycine max (L.) Merr. to the use of seaweed extract. Agronomy 2019, 9, 93. [CrossRef]

42. Szczepanek, M.; Siwik-Ziomek, A. P and K Accumulation by rapeseed as affected by biostimulant under different NPK and S fertilization doses. Agronomy 2019, 9, 477. [CrossRef]

43. Abd El-Gawad, H.G.; Osman, H.S. Effect of exogenous application of boric acid and seaweed extract on growth, biochemical content and yield of eggplant. J. Hortic. Sci. Ornam. Plants 2014, 6, 133-143. [CrossRef]

44. Manna, D.; Sarkar, A.; Maity, T.K. Impact of Biozyme on growth, yield and quality of chilli (Capsicum annuum L.). J. Crop Weed 2012, 8, 40-43.

45. Kumar, N.A.; Vanlalzarzova, B.; Sridhar, S.; Baluswami, M. Effect of liquid seaweed fertilizer of Sargassum wightii Grev. on the growth and biochemical content of green gram (Vigna radiata (L.) R. Wilczek). Recent Res. Sci. Technol. 2012, 4, 40-45.

46. Di Mola, I.; Cozzolino, E.; Ottaiano, L.; Giordano, M.; Rouphael, Y.; Colla, G.; Mori, M. Effect of vegetal- and seaweed extract-based biostimulants on agronomical and leaf quality traits of plastic tunnel-grown baby lettuce under four regimes of nitrogen fertilization. Agronomy 2019, 9, 571. [CrossRef]

47. Colla, G.; Cardarelli, M.; Bonini, P.; Rouphael, Y. Foliar applications of protein hydrolysate, plant and seaweed extracts increase yield but differentially modulate fruit quality of greenhouse tomato. HortScience 2017, 52, 1214-1220. [CrossRef]

48. Lötze, E.; Hoffman, E.W. Nutrient composition and content of various biological active compounds of three south African-based commercial seaweed biostimulants. J. Appl. Phycol. 2016, 28, 1379-1386. [CrossRef]

49. Moreira Sisalema, J.M. Comportamiento Agronómico del Cultivo de Soya (Glycine max L.), a la Aplicación de Tres Extractos de Algas Marinas, en la Zona de Puebloviejo. Available online: http://dspace.utb.edu.ec/ bitstream/49000/5048/1/TE-UTB-FACIAG-ING\%20AGROP-000018.pdf (accessed on 1 December 2019).

50. Marschner, H. Mineral Nutrition of Higher Plants; Academic Press: London, UK, 1995.

51. Pratelli, R.; Pilot, G. Altered amino acid metabolism in glutamine dumper1 plants. Plant. Signal. Behav. 2007, 2, 182-184. [CrossRef]

52. Stitt, M.; Müller, C.; Matt, P.; Gibon, Y.; Carillo, P.; Morcuende, R.; Scheible, W.R.; Krapp, A. Steps towards an integrated view of nitrogen metabolism. J. Exp. Bot. 2002, 53, 959-970. [CrossRef]

53. Colla, G.; Nardi, S.; Cardarelli, M.; Ertani, A.; Lucini, L.; Canaguiere, R.; Rouphael, J. Protein hydrolysates as biostimulants in horticulture. Sci. Hortic. 2015, 196, 28-38. [CrossRef]

54. Colla, G.; Rouphael, Y.; Canaguier, R.; Svecova, E.; Cadarelli, M. Biostimulant action of a plant-derived protein hydrolysate produced through enzymatic hydrolysis. Front. Plant Sci. 2014, 5, 448. [CrossRef]

55. Parrado, J.; Escudero-Gilete, M.L.; Frriaza, V.; Garcia-Martinez, A.; González-Miret, M.L.; Bautista, J.D.; Heredia, F.J. Enzymatic vegetable extract with bioactive components: influence of fertilizer on the colour and anthocyanins of red grapes. J. Sci. Food Agric. 2007, 87, 2310-2318. [CrossRef]

56. Ertani, A.; Pizzeghello, D.; Francioso, O.; Sambo, P.; Sanchez-Cortes, S.; Nardi, S. Capsicum chinensis L. growth and nutraceutical properties are enhanced by biostimulants in a long-term period: Chemical and metabolomic approaches. Front. Plant Sci. 2014, 5, 375. [CrossRef] [PubMed] 
57. Di Mola, I.; Ottaiano, L.; Cozzolino, E.; Senatore, M.; Giordano, M.; El-Nakhel, C.; Sacco, A.; Rouphael, Y.; Colla, G.; Mori, M. Plant-based biostimulants influence the agronomical, physiological, and qualitative responses of baby rocket leaves under diverse nitrogen conditions. Plants 2019, 8, 522. [CrossRef] [PubMed]

58. Liu, X.Q.; Ko, K.Y.; Kim, S.H.; Lee, K.S. Effect of amino acid fertilization on nitrate assimilation of leafy radish and soil chemical properties in high nitrate soil. Commun. Soil Sci. Plant Anal. 2008, 39, 269-281. [CrossRef]

59. Kocira, S.; Kocira, A.; Szmigielski, M.; Piecak, A.; Sagan, A.; Malaga-Toboła, U. Effect of an amino acids-containing biostimulator on common bean crop. Przem. Chem. 2015, 94, 1732-1736. [CrossRef]

60. Kocira, S.; Szparaga, A.; Kocira, A.; Czerwińska, E.; Depo, K.; Erlichowska, B.; Deszcz, E. Effect of applying a biostimulant containing seaweed and amino acids on the content of fiber fractions in three soybean cultivars. Legume Res. 2018, LR-412. [CrossRef]

61. Rouphael, Y.; De Micco, V.; Arena, C.; Raimondi, G.; Colla, G.; De Pascale, S. Effect of Ecklonia maxima seaweed extract on yield, mineral composition, gas exchange and leaf anatomy of zucchini squash grown under saline conditions. J. Appl. Phycol. 2017, 29, 459-470. [CrossRef]

62. Rouphael, Y.; Giordano, M.; Cardarelli, M.; Cozzolino, E.; Mori, M.; Kyriacou, M.C.; Bonini, P.; Colla, G. Plant and seaweed-based extracts increase yield but differentially modulate nutritional quality of greenhouse spinach through biostimulant action. Agronomy 2018, 8, 126. [CrossRef]

63. Duer, I.; Fotyma, M.; Madej, A. Kodeks Dobrej Praktyki Rolniczej, 3rd ed.; Fundacja Programów Pomocy dla Rolnictwa: Warszawa, Poland, 2004. (In Polish)

64. Craigie, J.S. Seaweed extract stimuli in plant science and agriculture. J. Appl. Phycol. 2011, 23, 371-393. [CrossRef]

65. Sharma, H.S.S.; Fleming, C.; Selby, C.; Rao, J.R.; Martin, T. Plant biostimulants: A review on the processing of microalgae and use of extracts for crop management to reduce abiotic and biotic stresses. J. Appl. Phycol. 2014, 26, 465-490. [CrossRef]

66. Bulgari, R.; Cocetta, G.; Trivellini, A.; Vernieri, P.; Ferrante, A. Biostimulants and crop responses: A review. Biol. Agric. Hortic. 2015, 31, 1-17. [CrossRef]

67. Kocira, A.; Kornas, R.; Kocira, S. Effect assessment of Kelpak on the bean yield (Phaseolus vulgaris L.). J. Cent. Eur. Agric. 2013, 14, 545-554. [CrossRef]

68. Rathore, S.S.; Chaudhary, D.R.; Boricha, G.N.; Gosh, A.; Bhatt, B.P.; Zodape, S.T.; Patolia, J.S. Effect of seaweed extract on the growth, yield and nutrient uptake of soybean (Glycine max) under rainfed conditions. S. Afr. J. Bot. 2009, 75, 351-355. [CrossRef]

69. Karthikeyan, K.; Shanmugam, M. Development of a protocol for the application of commercial bio-stimulant manufactured from Kappaphycus alvarezii in selected vegetable crops. J. Exp. Biol. Agric. Sci. 2016, 4, 92-102.

70. Tandon, S.; Dubey, A. Effects of Biozyme (Ascophyllum nodosum) biostimulant on growth and development of soybean [Glycine max (L.) Merill]. Commun. Soil Sci. Plant Anal. 2015, 46, 845-858. [CrossRef]

71. Zewail, R.M.Y. Effect of seaweed extract and amino acids on growth and productivity and some biocostituents of common bean (Phaseolus vulgaris L.) plants. J. Plant. Production Mansoura Univ. 2014, 5, 1441-1453. [CrossRef]

72. Abo-Sedera, F.A.; Shams, A.S.; Mohamed, M.H.M.; Hamoda, A.H.M. Effect of organic fertilizer and foliar spray with some safety compounds on growth and productivity of snap bean. Ann. Agric. Sci. Moshtohor 2016, 54, 105-118.

73. Sujatha, K.; Vijayalakshmi, V. Foliar application of Caulerpa racemosa seaweed extract as bio-stimulant for enhancement of growth and yield of blackgram (Vigna mungo L.). IJOART 2013, 2, 216-230.

74. Jasim, A.H.; Obaid, A.S. Effect of foliar fertilizers spray, boron and their interaction on broad bean (Vicia faba L.) yield. Sci. Pap. B Hortic. 2014, 58, 271-276.

75. Delchev, G.; Zhelyazkova, T.; Stoyanova, A. Stability valuation of some mixtures between foliar fertilizers and combined herbicides for the grain yield of durum wheat. Turk. J. Agric. Natur. Sci., Special Issue 2014, 1, 1128-1133.

76. El-Gamal, I.S.; Abd El-Aal, M.M.M.; El-Desouky, S.A.; Khedr, Z.M.; Abo Shady, K.A. Effect of some growth substances on growth, chemical compositions and root yield productivity of sugar beet (Beta vulgaris L.) plant. Middle East. J. Agric. Res. 2016, 5, 171-185.

77. Abdel-Mawgoud, A.M.R.; El-Bassiouny, A.M.; Ghoname, A.; Abou-Hussein, S.D. Foliar application of amino acids and micronutrients enhance performance of green bean crop under newly reclaimed land conditions. Aust. J. Basic \& Appl. Sci. 2011, 5, 51-55. 
78. Shafeek, M.R.; Hafez, M.M.; Mahmoud, A.R.; Ali, A.R. Comparative effect on N-fixing bacterial with foliar application of amino acid mixed on growth and yield of pea plants (Pisum sativum L.). Middle East. J. Appl. Sci. 2014, 4, 755-761.

79. El-Ghamry, A.M.; Abd El-Hai, K.M.; Ghoneem, K.M. Amino and humic acids promote growth, yield and disease resistance of faba bean cultivated in clayey soil. Aust. J. Basic Appl. Sci. 2009, 3, 731-739.

80. Sadak, M.S.H.; Abdelhamid, M.T.; Schmidhalter, U. Effect of foliar application of aminoacids on plant yield and some physiological parameters in bean plants irrigated with seawater. Acta Biol. Colomb. 2015, 20, 141-152.

81. Khan, W.; Rayirath, U.P.; Subramanian, S.; Jithesh, M.N.; Rayorath, P.; Hodges, D.M.; Critchley, A.T.; Craigie, J.S.; Norrie, J.; Prithiviraj, B. Seaweed extracts as biostimulants of plant growth and development. J. Plant Growth Regul. 2009, 28, 386-399. [CrossRef]

82. Santner, A.; Calderon-Villalobos, L.I.A.; Estelle, M. Plant hormones are versatile chemical regulators of plant growth. Nat. Chem. Biol. 2009, 5, 301-307. [CrossRef] [PubMed]

83. Depuydt, S.; Hardtke, C.S. Hormone signalling crosstalk in plant growth regulation. Curr. Biol. 2011, 21, 365-373. [CrossRef]

84. Sakakibara, H. Cytokinins: Activity, biosynthesis, and translocation. Ann. Rev. Plant Biol. 2006, 57, 431-449. [CrossRef]

85. Aremu, A.O.; Plačková, L.; Grúz, J.; Biba, O.; Novák, O.; Stirk, W.A.; Doležal, K.; Van Staden, J. Seaweed-derived biostimulant (Kelpak) influences endogenous cytokinins and bioactive compounds in hydroponically grown Eucomis autumnalis. J. Plant Growth Regul. 2016, 35, 151-162. [CrossRef]

86. Masondo, N.A.; Aremu, A.O.; Kulkarni, M.G.; Petř́k, I.; Plačková, L.; Šubrtová, M.; Novák, O.; Grúz, J.; Doležal, K.; Strnad, M.; et al. Elucidating the role of Kelpak ${ }^{\circledR}$ on the growth, phytohormone composition, and phenolic acids in macronutrient-stressed Ceratotheca triloba. J. Appl. Phycol. 2019, 31, 2687-2697. [CrossRef]

87. Kulkarni, M.G.; Rengasamy, K.R.R.; Pendota, S.C.; Grúz, J.; Plačková, L.; Novák, O.; Doležal, K.; Van Staden, J. Bioactive molecules derived from smoke and seaweed Ecklonia maxima showing phytohormone-like activity in Spinacia oleracea L. New Biotechnol. 2019, 48, 83-89. [CrossRef] [PubMed]

88. Crouch, I.J.; Smith, M.T.; Van Staden, J.; Lewis, M.J.; Hoad, G.V. Identification of auxins in a commercial seaweed concentrate. J. Plant Physiol. 1992, 139, 590-594. [CrossRef]

89. Jennings, R.C. Gibberellins as endogenous growth regulators in green and brown algae. Planta 1968, 80, 34-42. [CrossRef]

90. Yamaguchi, S. Gibberellin metabolism and its regulation. Annu. Rev. Plant Biol. 2008, 59, 225-251. [CrossRef]

91. Tanimoto, E. Gibberellins. In Plant Roots-The Hidden Half; Waisel, Y., Eshel, A., Kafkafi, U., Eds.; Marcel Dekker: New York, NY, USA, 2002; pp. 405-416.

92. Gopala, R.P. Gibberellin-like behaviour of $\alpha$-tocopherol in green gram Vigna radiata. Geobios 1984, 11, 21-25.

93. Jensen, A. Tocopherol content of seaweed and seaweed meal. I. Analytical methods and distribution of tocopherols in benthic algae. J. Sci. Food Agric. 1969, 20, 449-453.

94. Bajguz, A.; Hayat, S. Effects of brassinosteroids on the plant responses to environmental stresses. Plant Physiol. Biochem. 2009, 47,1-8. [CrossRef]

95. Divi, U.K.; Krishna, P. Overexpression of the brassinosteroid biosynthetic gene AtDWF4 in Arabidopsis seeds overcomes abscisic acid-induced inhibition of germination and increases cold tolerance in transgenic seedlings. J. Plant Growth Regul. 2010, 29, 385-393. [CrossRef]

96. Cambri, D.; Filippini, L.; Apone, F.; Arciello, S.; Colucci, G.; Portoso, D. Effect of Aminoplant ${ }^{\circledR}$ on expression of selected genes in Arabidopsis thaliana L. plants. In Biostimulators in Modern Agriculture: General Aspects; Gawrońska, H., Ed.; Wieś Jutra: Warszawa, Poland, 2008; pp. 77-82.

97. Maini, $P$. The experience of the first biostimulant, based on amino acids and peptides: A short retrospective review on the laboratory researches and the practical results. Fertilitas Agrorum 2000, 1, $29-43$.

98. Garcia, A.L.; Madrid, R.; Gimeno, V.; Rodriguez-Ortega, W.M.; Nicolas, N.; Garcia-Sanchez, F. The effects of amino acids fertilization incorporated to the nutrient solution on mineral composition and growth in tomato seedlings. Span. J. Agric. Res. 2011, 9, 852-861. [CrossRef]

99. Cerdán, M.; Sánchez-Sánchez, A.; Oliver, M.; Juárez, M.; Sánchez-Andreu, J.J. Effect of foliar and root applications of amino acids on iron uptake by tomato plants. Acta Hortic. 2009, 830, 481-488. [CrossRef] 
100. Ertani, A.; Cavani, L.; Pizzeghello, D.; Brandellero, E.; Altissimo, A.; Ciavatta, C.; Nardi, S. Biostimulant activities of two protein hydrolysates on the growth and nitrogen metabolism in maize seedlings. J. Plant Nutr. Soil Sci. 2009, 172, 237-244. [CrossRef]

101. García-Martínez, A.M.; Díaz, A.; Tejada, M.; Bautista, J.; Rodríguez, B.; María, C.S.; Revilla, E.; Parrado, J. Enzymatic production of an organic soil biostimulant from wheat condensed distiller solubles: effects on soil biochemistry and biodiversity. Process. Biochem. 2010, 45, 1127-1133. [CrossRef]

102. Lucini, L.; Rouphael, Y.; Cardarelli, M.; Canaguier, R.; Kumar, P.; Colla, G. The effect of a plant-derived protein hydrolysate on metabolic profiling and crop performance of lettuce grown under saline conditions. Sci. Hortic. 2015, 182, 124-133. [CrossRef]

103. Matsumiya, Y.; Kubo, M. Soybean peptide: Novel plant growth promoting peptide from soybean. In Soybean and Nutrition; El-Shemy, H., Ed.; InTech, 2011. Available online: http://www.intechopen.com/books/ soybean-and-nutrition/soybean-peptide-novel-plant-growth-promoting-peptide-from-soybean (accessed on 1 December 2019).

104. Schiavon, M.; Ertani, A.; Nardi, S. Effects of an alfalfa protein hydrolysate on the gene expression and activity of enzymes of TCA cycle and N metabolism in Zea mays L. J. Agric. Food Chem. 2008, 56, 11800-11808. [CrossRef]

105. Halpern, M.; Bar-Tal, A.; Ofek, M.; Minz, D.; Muller, T.; Yermiyahu, U. The use of biostimulants for enhancing nutrient uptake. Adv. Agron. 2015, 130, 141-174. [CrossRef]

106. Nardi, S.; Pizzeghello, D.; Schiavon, M.; Ertani, A. Plant biostimulants: physiological responses induced by protein hydrolyzed-based products and humic substances in plant metabolism. Sci. Agric. 2016, 73, 18-23. [CrossRef]

107. Selvam, G.G.; Sivakumar, K. Micromorphological study of Vigna mungo L. using seaweed liquid fertilizer from Hypnea musciformis (Wulf.) Lamouroux. Indian J. Mar. Sci. 2016, 45, 1199-1207.

108. John, P.P.J.; Yuvaraj, P. Effect of Seaweed Liquid Fertilizer of Colpomenia sinuosa (Mert. ex Roth) Derbes \& Solier (Brown Seaweed) on Vigna radiata (L.) R. Wilczek. in Koothankuzhi, Tirunelveli district, Tamil Nadu, India. Int. J. Pure Appl. Biosci. 2014, 2, 177-184.

109. Gugała, M.; Sikorska, A.; Zarzecka, K.; Findura, P.; Malaga-Toboła, U. Chemical composition of winter rape seeds depending on the biostimulators used. Agronomy 2019, 9, 716. [CrossRef]

110. Schubert, S.; Mengel, K. Important factors in nutrient availability: root morphology and physiology. Z. Pflanzenernähr. Bodenkd. 1989, 152, 169-174. [CrossRef]

111. Czewińska, E.; Szparaga, A. Antibacterial and antifungal activity of plant extracts. Rocz. Ochr. Sr. 2015, 17, 209-229.

112. Jindo, K.; Martim, S.A.; Navarro, E.C.; Pérez-Alfocea, F.; Hernandez, T.; Garcia, C.; Aguiar, N.O.; Canellas, L.P. Root growth promoting by humic acids from composted and non-composted urban organic wastes. Plant Soil 2012, 353, 209-220. [CrossRef]

113. Ertani, A.; Schiavon, M.; Muscolo, A.; Nardi, S. Alfalfa plant-derived biostimulant stimulate short-term growth of salt stressed Zea mays L. plants. Plant. Soil 2013, 364, 145-158. [CrossRef]

114. Cheynier, V.; Comte, G.; Davies, K.M.; Lattanzio, V.; Martens, S. Plant phenolics: Recent advances on their biosynthesis, genetics, and ecophysiology. Plant. Physiol. Biochem. 2013, 72, 1-20. [CrossRef]

115. Aremu, A.O.; Masondo, N.A.; Rengasamy, K.R.R.; Amoo, S.O.; Grúz, J.; Biba, O.; Šubrtová, M.; Pencık, A.; Novák, O.; Doležal, K.; et al. Physiological role of phenolic biostimulants isolated from brown seaweed Ecklonia maxima on plant growth and development. Planta 2015, 241, 1313-1324. [CrossRef]

116. Świeca, M.; Gawlik-Dziki, U.; Kowalczyk, D.; Złotek, U. Impact of germination time and type of illumination on the antioxidant compounds and antioxidant capacity of Lens culinaris sprouts. Sci. Hortic. 2012, 140, 87-95. [CrossRef]

117. Fan, D.; Hodges, D.M.; Critchley, A.T.; Prithiviraj, B. A commercial extract of brown macroalga (Ascophyllum nodosum) affects yield and the nutritional quality of spinach in vitro. Commun. Soil Sci. Plant Anal. 2013, 44, 1873-1884. [CrossRef]

118. Paul, K.; Sorrentino, M.; Lucini, L.; Rouphael, Y.; Cardarelli, M.; Bonini, P.; Reynaud, H.; Canaguier, R.; Trtílek, M.; Panzarová, K.; et al. Understanding the biostimulant action of vegetal-derived protein hydrolysates by high-throughput plant phenotyping and metabolomics: a case study on tomato. Front. Plant Sci. 2019, 10, 47. [CrossRef] 
119. Shalaby, S.; Horwitz, B.A. Plant phenolic compounds and oxidative stress: integrated signals in fungal-plant interactions. Curr. Genet. 2015, 61, 347-357. [CrossRef]

120. Gurav, R.G.; Jadhav, J.P. A novel source of biofertilizer from feather biomass for banana cultivation. Environ. Sci. Pollut. Res. Int. 2013, 20, 4532-4539. [CrossRef] [PubMed]

121. Wenda-Piesik, A.; Kazek, M.; Ropińska, P. Impact of amino acid biostimulation and microelements fertilization in foliar application on productivity of winter oilseed rape. Fragm. Agron. 2017, 34, 119-129. 